\title{
CONSERVAÇÃO DE HASTES DE CITROS DESTINADAS A
} ENXERTIA (*). ARY A. SALIBE e CARLOS ROESSING. Presentemente a citricultura brasileira passa por nova fase de desenvolvimento, decorrendo daí desusada procura de mudas cítricas, provenientes de matrizes de reconhecido valor e isentas de pragas e moléstias, principalmente aquelas de vírus.

Como a propagação racional dos citros em nosso meio é realizada pelo processo de enxertia por borbulhia, evidente se torna que boas mudas se obtêm partindo de borbulhas de boos matrizes. A obtenção dessas borbulhas demanda, por vêzes, o tronsporte de material fàcilmente perecível, por longas distâncias. Utilizam-se então os mais variados métodos de acondicionamento do material, procurando mantê-lo em condições de oferecer um elevado indice de pegamento por ocasião da enxertia. Outras vêzes acontece que, obtidas as borbuIhas, condições climáticas adversas ou fatôres outros, independentes da vontade do citricultor, obrigam-no a retardar a operação da enxertia.

Procurando obter dados que permitam indicar métodos satisfatórios de acondicionamento das hastes de laranjeira, realizou-se o ensaio preliminar cujos resultados são apresentados no presente trabalho.

Material e método. Usou-se como variedade-enxêrto a laranjeira Hamlin, pelo excelente estado vegetativo das plantas matrizes e grande homogeneidade das hastes delas obtidas. Foram preparadas hastes de 30 a $35 \mathrm{~cm}$ de comprimento, roliças, apresentando 10 a 12 borbulhas, das quais foram sempre aproveitadas para enxertia as cinco situadas na parte mais central.

As hastes foram retiradas a 14 de janeiro de 1958, misturadas e separadas em lotes de 15.

Foram ensaiados sete processos (tratamentos) de conservação das hastes:

1.) hastes em saquinho plástico - um dos lotes de hastes foi mergulhado em água limpa e a seguir colocado em saquinho plástico, cuja abertura foi firmemente amarrada com barbante; os saquinhos foram conservados em lugar fresco;

(*) Recebida para publicação em 16 de outubro de $195^{\circ}$. 
$2^{\circ}{ }^{\circ}$ hastes em saquinho plástico conservado na geladeira método idêntico ao anterior sendo os saquinhos, porém, conservados em geladeira, à temperatura de $6-8^{\circ} \mathrm{C}$;

3. ) hastes em areia - as hastes foram deitadas em camada simples numa caixa contendo areia e recobertas com nova camada de areia, de aproximadamente $20 \mathrm{~cm}$ de espessura; regou-se em seguida com água suficiente para umedecer bem a areia $(250 \mathrm{cc})$; as caixas foram conservadas em lugar fresco sendo a umidade da areia mantida mais ou menos constante, pela adição de novas quantidades de água;

4. ${ }^{\circ}$ hastes envoltas em papel umedecido - método comumente usado; as hastes foram amarradas em feixe enrolado em papel de jornal, mantido sempre umedecido;

5. ) hastes parafinadas - tôdas as hastes de um lote foram imersas completamente em parafina derretida; durante essa operação a parafina foi mantida numa temperatura suportável ao tato; as hastes parafinadas foram conservadas em lugar fresco e sêco;

$\left.6^{\circ}\right)$ hastes com a extremidade mergulhada em água -. foram parafinadas as extremidades superiores $(1 \mathrm{~cm})$ das hastes, sendo as inferiores mantidas sempre em água $(3 \mathrm{~cm}$ de altura); essa água era renovada cada dois dias;

7. $\left.{ }^{\circ}\right)$ hastes tratadas com calda bordalesa e mantidas em saquinhos plásticos - visando prevenir o aparecimento de fungos merguIharam-se hastes inteiras em calda bordalesa a $2 \%$, sendo a seguir conservadas em saquinhos plásticos, como em 1 .

A conservação das hastes se fêz durante 18 dias, e nesse espaço de tempo, em datas pré-fixadas, delas foram retiradas as borbulhas para enxertia, a fim de comparar as porcentagens de pegamento entre os diferentes sistemas de conservação.

Como porta-enxêrto utilizou-se a laranjeira Caipira, empregando-se "seedlings" de um viveiro bastante uniforme e do qual foram eliminados todos aquêles fracos ou de grossura inadequada. Esse viveiro foi dividido em lotes, cabendo a cada um dêles, por sorteio ao acaso, uma data de enxertia, a saber: 


$\begin{array}{cccc}\text { Lote } & \text { Data de enxertia } & \text { Lote } & \text { Data de enxertia } \\ \text { A } & 1-2-1958 & \text { F } & 18-1-1958 \\ \text { B } & 14-1-1958 & \text { G } & 22-1-1958 \\ \text { C } & 30-1-1958 & \text { H } & 24-1-1958 \\ \text { D } & 20-1-1958 & \text { I } & 16-1-1958 \\ \text { E } & 26-1-1958 & \text { J } & 28-1-1958\end{array}$

Cada lote foi por sua vez subdividido em parcelas. cada uma delas constituida de cinco plantas (em cada parcela foram deixados "seedlings" de reserva, para substituirem aquêles que não dessem casca por ocasiāo da enxertia).

Nas datas de enxertia tomavam-se três hastes de cada tratamento, enxertando-se as cinco borbulhas centrais de cada uma. Cada parcela era, pois, composta de cinco cavalos enxertados e cada tratamento, em cada data de enxertia, era testado com $5 \times 3=15$ enxertias.

Nas mesmas datas foram também enxertadas borbulhas provenientes de hastes retiradas das plantas matrizes na data da enxertia, sem qualquer tratamento prévio.

Tôdas as enxertias foram realizadas no período da manhã, por um único enxertador operando sempre da mesma maneira, introduzindo a borbulha em incisão em $\mathbf{T}$ invertido e numa mesma exposição: noroeste. As observações sôbre pegamento foram realizadas 20 dias após a data de enxertia.

Resultados - os pegamentos dos enxertos variaram de 0 a 5 , havendo, portonto, casos de completo fracasso e outros de pleno sucesso. Os dados numéricos obtidos foram transformados em porcentagens e com as porcentagens médias de cada tratamento foram construidas as curvas da figura 1.

Na figura 1 não foram representados os dados referentes ao tratamento 7 (hastes tratadas com calda bordalesa), porque em nenhum caso de enxertia dêsse tratamento houve pegamento. Nela também não constam os dados relativos às hastes retiradas nas datos de enxertia, que deram sempre $100 \%$ de pegamento, exceção aberta para os enxertos feitos em 16-1, 22-1 e 26-1, respectivamente com 93,3\%, $86,6 \%$ e $80,0 \%$ de sucesso.

Pelo exame das curvas da figura 1 observa-se que em todos os tratamentos ocorreu uma irregularidade na sucessão dos dados que 
exprimem o número de enxertias bem sucedidas. Tal irregularidade, que aliás não ocorreu com os enxertos procedidos com as borbulhas retiradas de hastes preparadas nas datas de enxertia, impediu a análise estatística dos resultados. Todavia elas serão objeto de estudos posteriores, a fim de esclarecer a questão em definitivo.

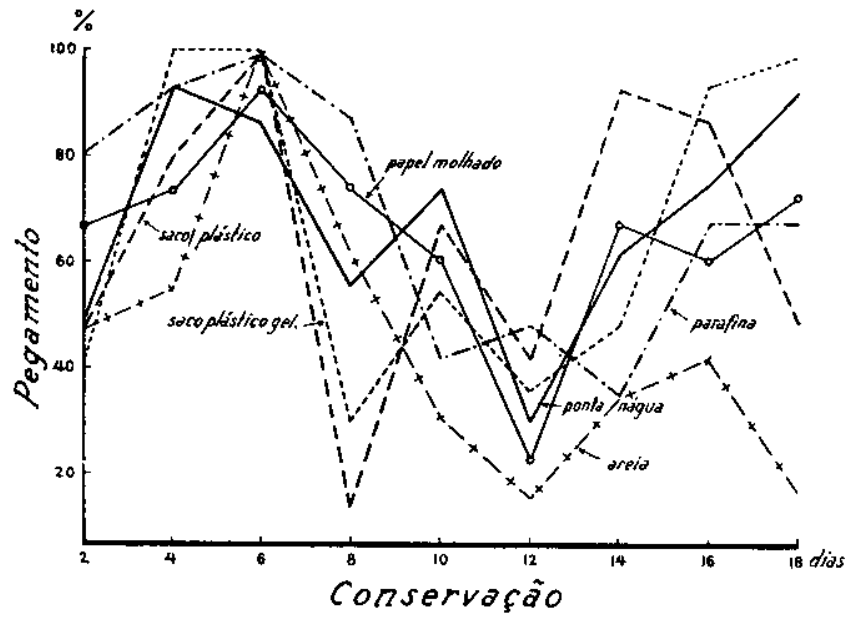

FIGURA 1. - Curvas de porcentogens de pegomento de borbuthas de laranja Hamlin enxertadas em cavalos de laranja Coipira, após conservaçāo dos hostes da variedade-enxêrto por diferentes métodos e durante número variável de dias.

Seja com fôr, baseados nos resultados preliminares aqui relatados bem como no exame do estado de conservação das estacas no final do período de 18 dias, podemos indicar provisòriamente como os mais eficientes os métodos de conservação das hastes em sacos plásticos, a $6-8^{\circ} \mathrm{C}$ e d̀ temperatura ambiente. SEÇÃO DE CITRICULTURA E ESTAÇÃO EXPERIMENTAL DE LIMEIRA, INSTITUTO AGRONOMMICO DO ESTADO DE SÃO PAULO.

\section{A COMPARISON OF STORAGE METHODS FOR CITRUS BUDWOOD}

\section{SUMMARY}

Seven methods of storing citrus budwood were compared. Keeping the bud sticks in tight plastic bogs maintained at $6{ }^{\circ}-8^{\circ} \mathrm{C}$ gove the best results. Storage in plastic bags at room temperature also gave good results. Budwood kept according to these methods gave satisfactory results when budded after 18 days in storage. 